\title{
$\mathbf{E}$

2013, Vol. 1, No. 1

\section{The Internationalization Process - A Case Study of PWPW S.A.}

\author{
Remigiusz Lewandowski, Grażyna Rafalska
}

\begin{abstract}
A B S T R A C T
Objective: The purpose of the paper is to present the implementation process of internationalization using the example of Polish Security Printing Works (PWPW) and to examine whether the process follows leading internationalization theories.

Research Design \& Methods: The paper is based on a literature review and a case study of PWPW. The methodology of a case study allows showing the researched process of a single firm's internationalization more precisely and thoroughly than quantitative research. The case study presents the whole internationalization process of PWPW, including a selection of its foreign activities.

Findings: The paper leads to the conclusion that the internationalization of PWPW generally remains in accordance with the revitalized Uppsala model. Nonetheless, there are some deviations from the model. They may result from the specificity of the business sector of PWPW. An example of such deviations is pushing customers actions towards a specified mode of supplier's internationalization.

Implications \& Recommendations: Empirical knowledge resulting from thoroughly studied behaviour of a required number of companies may significantly improve understanding of the internationalization process and point out the best solutions as well as solutions that should be avoided in business practice. It seems that the internationalization pattern of PWPW S.A. may be perceived as successful and therefore be applicable by other companies from the industry.

Contribution \& Value Added: The paper delivers new empirical evidence on internationalization practices pursued by PWPW, a company that delivers products having a critical influence on the state security.

\begin{tabular}{ll}
\hline Article type: & research paper (case study) \\
Keywords: & internationalization; exports; Uppsala model; PWPW S.A. \\
JEL codes: & F23, M16
\end{tabular}

Published by Centre for Strategic and International Entrepreneurship - Krakow, Poland
\end{abstract}

\section{Suggested citation:}

Remigiusz, L., Rafalska, G., (2013). 'The Internationalization Process - A Case Study of PWPW S.A.'. Entrepreneurial Business and Economics Review, 1(1), pp. 55-76. 


\section{INTRODUCTION}

International expansion is one of corporate strategies of development. It usually aims at additional revenues and margins from international markets. Sometimes it brings additional value based on extra knowledge acquired on such markets. If it is the case, such knowledge (in terms of technology, service, sales etc.) should be effectively utilized both on domestic and foreign markets. Nowadays the global economy conditions generate large opportunities for foreign entry. The legal and political entry barriers gradually decline, which generates expansion possibilities. Central and Eastern European companies also take part in this expansion process. They possess some competitive advantages such as low costs. In order to retain or strengthen their position it is necessary to create more durable competences. International expansion requires a mix of right competitive advantages and a strategy of entering foreign markets. This paper is focused on the internationalization process and the sequence of commitment decisions concerning internationalization.

\section{LITERATURE REVIEW}

When a company decides to enter foreign markets, it faces a range of options when choosing its internationalization strategy. The contemporary literature in the field presents numerous internationalization theories. The most important ones include: the technology gap theory and product life cycle theory, Dunning's eclectic paradigm, network approach, stage theories. The theory of technology gap and the theory of product life cycle belong to the group of neo-technology theories. These theories link the reasons and directions of international expansion of companies with some differences in technological development of different countries, i.e. with a technology gap. According to the technology gap theory (Posner, 1961; Krugman, 1979), more technologically developed countries have an easier access to foreign markets and mainly export innovative products and new technology knowledge. Less developed countries (in terms of technology) export non-innovative products and they use lower manufacturing costs as the base of their competitive advantage.

Vernon's concept of product life cycle (Vernon, 1966) shows the model of international expansion as a three-stage process that includes a stage of the new (innovative) product, a stage of the maturing product and a stage of the standardized product. The model assumes that each stage of internationalization has different requirements in terms of the location of manufacturing, exports and imports. Consequently, producers in advanced countries are closer to the markets than producers elsewhere and therefore the first production facilities are located in these advanced countries. Together with growing demand a certain degree of standardization takes place and economies of scale as well as production costs are becoming more important. Therefore, less developed countries with lower production costs can offer a competitive advantage for these products and that is why production locations change.

Vernon's approach has been modified both by Vernon (1979) himself and other researchers (e.g. Hirsch, 1975; Williamson, 1975) in such a way that it took into account the development of global networks of subsidiaries by leading multinational enterprises (MNEs) as well as the fact that the US market was no longer unique among national markets either in size or factor cost configuration. 
Dunning's eclectic paradigm is based on an assumption that a full explanation of the firm's internationalization needs to draw on several strands of economic theory. According to Dunning (1988) the firm's propensity to go international increases if there are three advantages met: ownership, locational and internalization. Ownership advantages take place when a firm which owns foreign production facilities has bigger ownership advantages compared to firms of other nationalities. Locational advantages (low wages, special taxes or tariffs, existence of raw materials) refer to the alternative countries or regions for undertaking the value adding activities of MNEs. Internalization advantages (advantages coming from own production rather than producing through a partnership arrangement such as licensing or a joint venture) are based on an assumption that the greater the net benefits of internalizing cross-border intermediate product markets, the more likely a firm will prefer to engage in foreign production itself rather than license the right to do so.

The model has been criticized due to very strict assumptions concerning instant and complete information possessed by the firm, unlimited information processing capacity and perfect qualifications for evaluating information (Daszkiewicz \& Wach, 2012, p. 69). That is why it is more suitable for large rather than small companies. Empirical findings confirm that the theory is suitable for the US market of service industry (Agarval, 1994) as well as Central and Eastern European markets (Nakos \& Brouthers, 2002).

The network approach is based on business relationship networks. There are many types of networks and different criteria of their classification. However, the basic mechanism of network internationalization is based on a process in which relationships are continuously established, developed, maintained and dissolved with the aim of achieving objectives of the firm (Daszkiewicz \& Wach, 2012, p. 81). According to Johanson and Matts (1988) the process of internationalization should be analysed from two perspectives: a degree of internationalization of the network and a degree of internationalization of the firm. Such an analysis enables us to identify four types of companies, i.e. the early starter, the late starter, the lonely international and the international among others.

There is empirical evidence supporting the network approach, yet usually limited to certain types of industry (e.g. software industry, Zain \& Ng, 2006). Therefore, the results should not be generalized.

Among many theories and models of internationalization the stage theories have been one of the most influential and popular in studying the process of the firm's internationalization (Gorynia \& Jankowska, 2007; Malhorta \& Hinings, 2010; Przybylska2010). The most famous stage model, often regarded as the pioneering one is Johanson and Vahlne's proposal from 1977 (Daszkiewicz \& Wach, 2012, p. 65), named "Uppsala model" after the researchers' place of academic work, i.e. the Uppsala University.

\section{The Revisited Uppsala Model}

According to the Uppsala model (Johanson \& Vahlne, 1977; Johanson \& Vahlne, 2009) foreign expansion of firms begins with ad hoc export activity and then progresses to exporting into neighbouring markets, followed by the stage of gradual penetration of other markets and an increased range of expansion forms as such. The implementation 
of each internationalization stage is a consequence of generating certain capabilities required for further international expansion. This capability is the function of all variables shaping the given stage (phase) of internationalization: knowledge, opportunities and position in a network of relationships, which in turn affect the organization's learning process, trust-building and the decision to proceed with expansion and relationship- and/or network-building. Such an incremental approach to internationalization based on the revitalized Uppsala model is presented in table 1.

Table 1. The internationalization of the firm - the incremental approach

\begin{tabular}{|c|c|c|c|c|c|c|}
\hline $\begin{array}{r}\text { Mode of } \\
\text { expansion }\end{array}$ & Ad hoc exports & \begin{tabular}{|l} 
Export sales \\
through own sales \\
representatives
\end{tabular} & $\begin{array}{l}\text { Exports sales } \\
\text { through local sales } \\
\text { representatives } \\
\text { and agents }\end{array}$ & Strategic alliances & $\begin{array}{l}\text { Foreign branches } \\
\text { and divisions }\end{array}$ & $\begin{array}{l}\text { Foreign production } \\
\text { and sales }\end{array}$ \\
\hline Market A & & Growing market & ngagement & & & \\
\hline Market B & 今. & & & & & \\
\hline Market C & $\begin{array}{l}\frac{0}{00} \\
\frac{1}{3} \\
\frac{\partial}{3}\end{array}$ & & & & & \\
\hline & 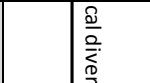 & & & & & \\
\hline Market N & $\Downarrow$ & & & & & \\
\hline
\end{tabular}

Source: adopted from (Hollensen, 2001, p. 48)

The model is dynamic. The outcome of one cycle of internationalization events constitutes the input of the next. There are two aspects of internationalization variables in the basic mechanism of internationalization: state and change aspects. The state aspects cover the resource commitment to the foreign markets (market commitment) and knowledge about foreign markets and operations. The change aspects are decisions to commit resources and the performance of current business activities. The original Uppsala model of 1977 (Johanson \& Vahlne, 1977) has been revisited. In their new model of 2009 (Johanson \& Vahlne, 2009) researchers adjusted the model to the current economic environment. Therefore, they have added "recognition of opportunities" to the "knowledge" variable and replaced "market commitment" with "network position" as they assumed that the internationalization process is pursued within a network. Moreover, they changed the original variable of "current activities" to "learning, creating, and trust-building" to make the outcome of current activities more explicit. Finally, the "commitment decisions" variable was extended to "relationship commitment decisions" variable in order to clarify that commitment is related to networks of relationships. The revisited basic mechanism of internationalization is illustrated in Figure 1. 


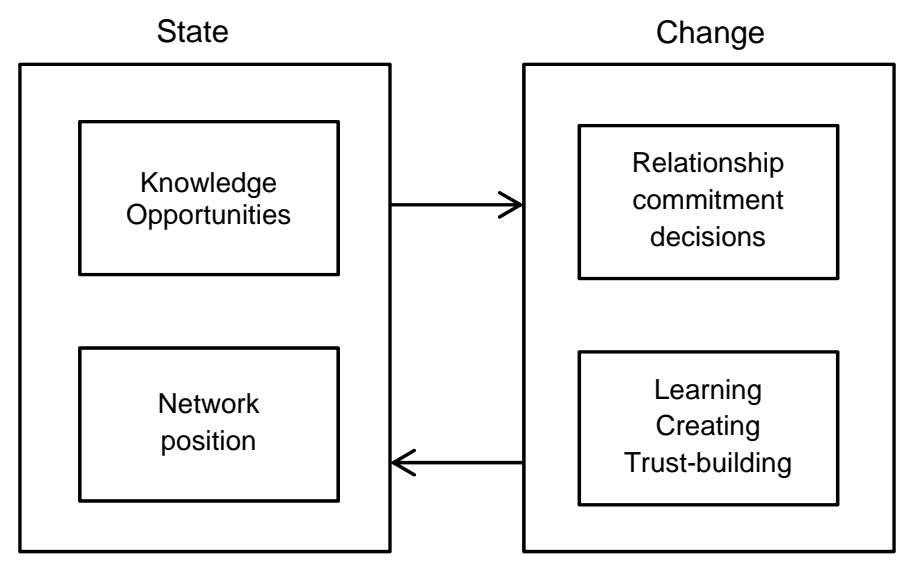

Figure 1. The basic mechanism of internationalization

Source: (Johanson \& Vahlne, 2009, p. 1424)

There are mixed empirical findings concerning the Uppsala model. Some of them support the incremental approach provided by the Uppsala School (e.g. Johanson \& Wiedersheim-Paul, 1975; Juul \& Walter, 1987). However, other studies suggest alternatives to incremental behaviour of firms that go international (e.g. Bonnaccorsi, 1992; Knight \& Cavusgil, 1996; Loane \& Bell, 2006; Zahra, Ireland \& Hitt, 2000). Numerous researchers identified the so-called leapfrog approach in terms of internationalization (e.g. Hedlund \& Kverneland, 1984; Nordström, 1990) and many others - born global firms (e.g. Simon, 1999; Miesenbock, 1985).

What is more important, scholars have questioned some of assumptions of the Uppsala model, such as one-directional process (Gorynia \& Jankowska2007) or narrow and rigid nature of its specification of the pattern that characterizes the incremental process (Petersen \& Pedersen 1997). Research on internationalization of Polish companies also does not give conclusive results. According to Maleszyk (2007) internationalization of Polish firms start with exports and then gradually transforms into more advanced modes, such as foreign branches and sales through local distributors on foreign markets. On the other hand Przybylska's (2010) case study leads to the conclusion that internationalization of Polish firms does not apply to the Uppsala model.

The mixed empirical results suggest that the Uppsala model is not universal. According to Bridgewater (2000) the model is not applicable in cases of certain products and services. Other studies show that internationalization strategies of manufacturing firms may differ from those of service firms due to unique characteristics of the latter and different strategic challenges (e.g. Goerzen \& Makino, 2007; Barkema \& Drogendijk, 2007; Capar \& Kotabe, 2003). Erramilli (1991) argued that service firms have greater latitude than manufacturing companies in establishing high resource commitment modes of operation since they incur lower overheads and can redeploy resources easily. 


\section{Role of Distance in Internationalization Attempts}

Practical experience and scientific research confirm that distance between the parties to a given business transaction plays an important role in the internationalization process. In this case distance can be understood both in geographical and cultural terms, which, to some extent, is also connected with physical distance. Hence, the choice of directly neighbouring countries as the target market comes naturally.

In the case of Poland, foreign expansion to neighbouring markets may go in two directions. The first direction is Central and Eastern Europe. This is connected with relative weakness of local companies (as compared with Polish and Western European firms) and a high absorption of the economy consuming imported products and services. In the aforementioned part of Europe, Polish companies have strategic advantage over Western European and non-European businesses competing in this region, based on the cultural and geographical proximity. As Domarecki (2012, p. 18-19) points out, this proximity facilitates movement within the local environment of the region and affects transportation and maintenance costs. The second direction of Polish exports is Western Europe. This market is far more challenging than CEE due to the stable and strong position of local firms. Nevertheless, statistical data on the structure of Polish exports indicates that European countries remain the core export recipients, with the developed countries at the top of the list.

Table 2. Foreign trade turnover of Poland

\begin{tabular}{|l|r|r|}
\hline \multicolumn{1}{|c|}{ Specification } & 1H2013 (million PLN) & \% share \\
\hline Total exports & 307036 & 100.0 \\
\hline Developed countries & 250418 & 81.6 \\
\hline of which EU & 228247 & 74.3 \\
\hline of which Eurozone & 155830 & 50.8 \\
\hline Developing countries & 27528 & 9.0 \\
\hline Eastern and Central Europe & 29090 & 9.5 \\
\hline
\end{tabular}

Source: Polish Central Statistical Office, http://www.stat.gov.pl/gus/wyniki_wstepne_PLK_HTML.htm

As shown in Table 2, Polish export to developed EU economies represents $74.3 \%$ of total value. Export to European developing economies is much lower and account for just $9.5 \%$ of total value. Major recipients of Polish exports include Germany, which accounts for $25 \%$ of total export. The other importing countries have much lower shares. For instance, the second largest recipient of Polish exports purchased goods and services amounting to 19.6 bln PLN or $6.4 \%$ of total exports in $1 \mathrm{H} \mathrm{2013.} \mathrm{The}$ countries with shares of 2 to $5 \%$ include some developing economies such as the Czech Republic (6.1\%), Russia (5.3\%),Ukraine (2.7\%) and Slovakia (2.6\%). Detailed information is presented in Table 3. 
Table 3. Foreign trade turnover of Poland broken down into major importing countries

\begin{tabular}{|c|l|r|r|}
\hline No. & \multicolumn{1}{|c|}{ Country } & $\mathbf{1 H 2 0 1 3}$ (million PLN) & \% share \\
\hline 1 & Germany & 76679 & 25.0 \\
\hline 2 & UK & 19554 & 6.4 \\
\hline 3 & Czech Republic & 18684 & 6.1 \\
\hline 4 & France & 17858 & 5.8 \\
\hline 5 & Russia & 16328 & 5.3 \\
\hline 6 & Italy & 13878 & 4.5 \\
\hline 7 & Netherlands & 11940 & 3.9 \\
\hline 8 & Sweden & 8446 & 2.8 \\
\hline 9 & Ukraine & 8321 & 2.7 \\
\hline 10 & Slovakia & 7955 & 2.6 \\
\hline
\end{tabular}

Source: Polish Central Statistical Office, http://www.stat.gov.pl/gus/wyniki_wstepne_PLK_HTML.htm

Concentration on European countries, in particular Poland's neighbours, is also reflected in the structure of foreign entities of Polish companies. In 2011 business entities located in Poland invested capital in 94 countries and there were 3187 Polish entities abroad. The legal form of invested capital covered mainly shares in companies, divisions and facilities. The chief countries hosting Polish entities abroad are Germany, Ukraine and the Czech Republic. Details are presented in Figure 2.

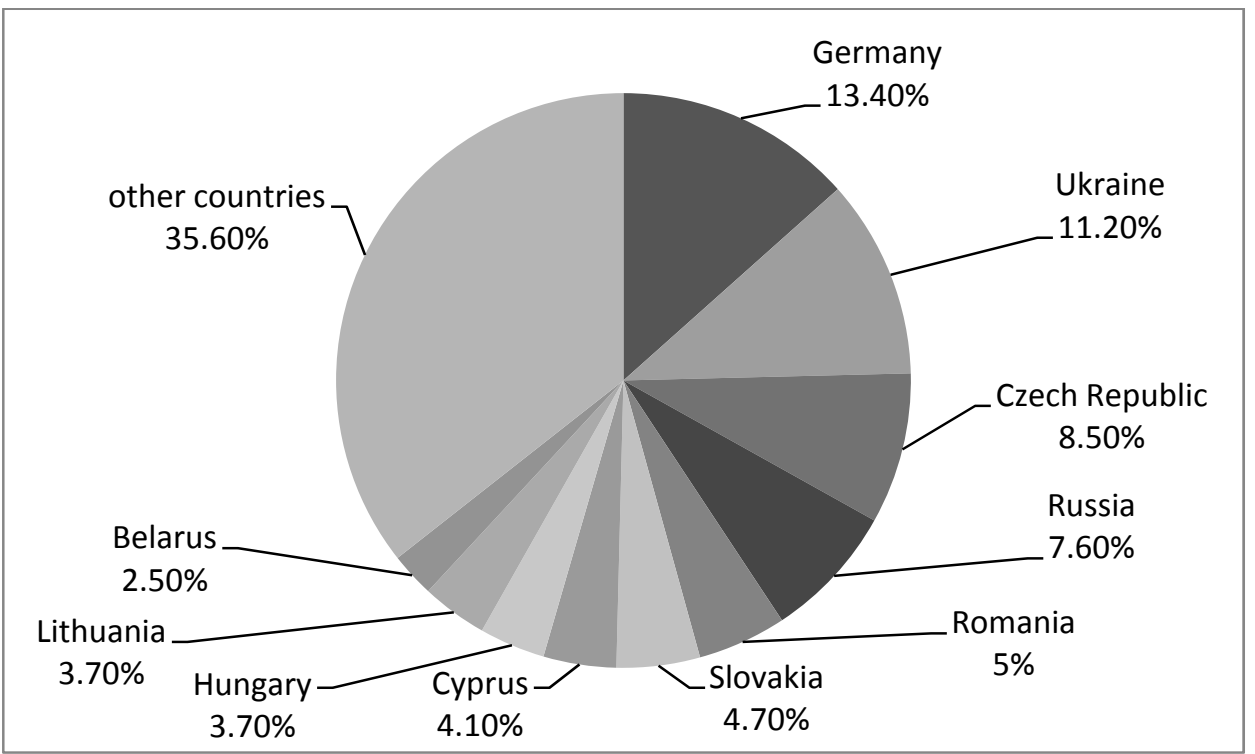

Figure 2. Structure of Polish business entities abroad

Source: Polish Central Statistical Office, http://www.stat.gov.pl/gus/wyniki_wstepne_PLK_HTML.htm

Yet for some sectors distance is moderated by political and national security interests in which case geographic proximity plays a secondary role. For example, on the Western European market the sector dealing with documents and associated telecommunication and information systems is closed to external entities and new players. In countries with national printing works, the markets are often protected by legal monopolies, which are established for national security reasons (e.g. France, 
Spain, Portugal). In some countries (such as Germany) the prevailing status quo means that the national producer is the obvious and natural supplier of documents for public administration. This policy is reflected in the statement made by a German MP, HansPeter Uhl, who in 2008 demanded that "production of our [German] documents remain in German hands", in fact speaking on behalf of all political groups represented in the German Parliament (Die Welt, 2008).

\section{MATERIAL AND METHODS}

The presented leading theories of internationalization most often rely on research conducted in developed countries. They are usually based on findings concerning countries with a significant experience with international trade and free market economy. Even so, the theories confronted with empirical findings, surprisingly, produce mixed results. There is no universal internationalization model that applies to each country or even industry. Therefore, the patterns of the firm's internationalization in developing countries, e.g. of Central and Eastern European, as well as schemes of decision making processes in terms of internationalization, are an interesting and necessary field of research.

When analysing various concepts of the internationalization process of the firm, it is particularly important to confront theoretical models with the business practice. In this context, cross-sectional research, covering various companies or (what enhances the value of such studies) various sectors of the economy, plays an important role. However, case studies of individual firms give a highly useful, detailed view of corporate internationalization strategies. Authors point out that information collected with case study methodology are more detailed and precise than data collected with the use of statistical methods (Przybylska, 2010, p. 149). This type of research provides a thorough analysis of the internationalization process and its cause-and-effect components. Moreover, as Adamkiewicz-Drwiłło (2008, pp. 138-139) points out, a management theory should aim not only to describe the reality but also to provide problem solutions and, to present examples of wrong management and best practice. The findings of such research should not be generalized but rather seen as deeper justification of the general conclusions drawn from cross-sectional studies. Thus, this paper is based on a case study methodology, with the use of Polish Security Printing Works (PWPW) as a researched subject of internationalization.

The case study is based on the authors' professional knowledge on PWPW'S foreign operations. Both authors work at PWPW, one as International Sales Director and the other as Strategy Director. The data used in the case study has been collected from internal sources of PWPW, both published and unpublished documents.

The objective of the study described in this paper is to present the internationalization process of PWPW. For the purpose of this study internationalization is understood as the process of a company's expansion into foreign markets. The form of the expansion includes exports, licensing, franchising, joint ventures, as well as foreign branches, divisions, facilities and companies. Relatively often, internationalization takes the form of strategic alliances formed by trade companies in the course of foreign expansion or shared procurement initiatives (Komor, 2011, p. 74). 
The research assumption is that internationalization activities of PWPW remain in accordance with the revisited Uppsala model. Companies that manufacture products, which are important from the point of view of national security, need time to establish international relationships with end customers based on trust and reliability. Customers like central banks and governments, need to be sure that a producer from a foreign market ensures that their national security will not be violated through insufficient quality of ordered products or misuse of products/technology specifications. Therefore, one may expect that security printing industry develops its international activities gradually in accordance with the stage theories of internationalization.

The choice of PWPW as a subject of the case study results from two reasons. First of all, it allows drawing conclusions on the internationalization process taken by a manufacturer of secured products of critical influence on the state security. Research on the internationalization process of such companies is not very common. Secondly, it is a state-owned enterprise. This feature helps to analyse whether the shareholders' nature (private or state) is a factor which influences the internationalization process. Thus, it seems that the case study of PWPW's internationalization may bring new evidence on a unique type of industry represented by this company.

\section{RESULTS AND DISCUSSION: INTERNATIONALIZATION ON THE EXAMPLE OF PWPW S.A.}

\section{Scope of Activities}

Today, PWPW is mainly engaged in two business areas: support of identification processes and support of transaction processes. These two areas of PWPW's activities comprise both traditional and electronic/computerized security features. It is PWPW's mission to enhance the reliability of transaction and identification processes through its products and services. This mission is pursued in PWPW's current operations. Production of blank identity cards, passport booklets, driving licenses or vehicle registration cards are the most prominent examples of the company's presence in the identification area. The company also integrates traditional identification products with IT solutions, such as the digital signature. Modern personalization technologies enable PWPW to fully own the value chain of transport documents. It should be emphasized that PWPW competencies include not just perfectly-secured physical carriers of identification information, but also IT systems for the administration and management of such carriers and data transfer. The combination of all competencies required in document processing in one value chain, as offered to PWPW customers, is a big challenge facing global companies aspiring to act as IT system integrators for the state.

Apart from supporting identification processes, PWPW is also an active player on the market for transaction support services. As previously explained, the company's activities cover both transaction carriers and the services required for their implementation. PWPW produces banknotes, cheques, postal stamps, payments cards and is developing a range of services to ensure the reliability of transaction processes. This is reflected in the initiative implemented at PWPW's subsidiary, Polskie ePłatności S.A., to create networks for the acceptance, authorization and settlement of non-cash payments (i.e. with the use of cards, through POS) all around Poland. 
PWPW is the only company in Poland capable of ensuring a full range of services to the state with regard to the delivery of banknotes and documents and the associated IT systems, covering very specific and sensitive solutions for the personalization of citizen personal data, cryptography or biometric methods.

The above examples prove that the company is actively pursuing its mission and, as an enterprise based in Poland, it is strengthening its position with regard to ensuring reliability of identification and transaction processes. PWPW's expansion into economic sectors which it has not explored on the domestic market and the creation of new markets (through innovations) is motivated by the need to take certain anticipatory actions due to progressing life cycles of existing products and aging traditional markets. At the same time, as the core domestic market of PWPW's operation is limited, the company is also expanding into foreign markets. These are mainly countries without their own banknote or security printing entities, due to their small size or lower economic advancement.

\section{Incremental Internationalization of PWPW}

Polish Security Printing Works has produced Polish banknotes and the most important public documents for over 90 years. However, at the beginning of the 21st century export contracts were still an exception rather than a rule in its daily operations. These were mainly ad hoc orders, often executed in cooperation with other producers of security prints or as a subcontractor for large players on a given market. At this stage of PWPW's internationalization there was hardly any real export activity. It was rather a form of (limited) readiness to process certain foreign orders submitted the ordering party's initiative. This ad hoc export activity covered countries such as Ukraine or Belarus and was carried out as a part of technological cooperation with companies of a similar business profile and less manufacturing experience. At the same time, PWPW was a trusted subcontractor of German companies, without the possibility of obtaining references or enhancing its reputation with end customers. The concept of trust is crucial in the business of banknote and ID manufacturing, which is a part of national security (Lewandowski, 2014). The relationship between the customer (the government or the central bank) and the producer of banknotes, passports or ID cards can be established only when the producer confirms that the national security of the client is ensured. It takes time to establish such a position on the international market which has been built on trust and reliability.

\section{Period of ad hoc Export Activity}

As PWPW's activity was focused on the domestic market, it had no internal unit responsible for foreign exports. However, the sales representatives and technology experts engaged in foreign orders were knowledgeable about the specifics of the given foreign market. This covered not only different expectations and solutions in terms of technology, quality and deadlines, but also differences in relationships and culture. It should be emphasized that such trade contracts were executed mainly with other banknote and document producers (on a subcontract basis) and not with the end customers (public administration bodies or central banks). As a result, PWPW formed its first relationships with representatives of entities which were in fact its competitors on the foreign market. 
Nevertheless, it was only after Poland's EU accession that there appeared real opportunities for extensive export development. This was mainly due to profound changes in Polish legislation and regulations concerning the issue of documents and banknote printing, opening of new sale markets (Poland and EU member states) and creation of new standards of international trade. For PWPW the year 2004 was also important due to its acquisition of Drukarnia Skarbowa S.A. and expansion of its product range by identity cards, passports and other products.

The above period, starting from the company's commercialization in 1996 up until 2007, can be seen as the first step into the internationalization of the firm and its sale operations. During that period, four key factors were at stake:

1) knowledge and opportunities,

2) network position,

3) learning and trust-building,

4) decisions on further engagement in the relationship and/or network-building.

The knowledge factor has been an important element in the process of building PWPW's international position. This knowledge has included mainly:

1) technological expertise and know-how,

2) logistical issues,

3) knowledge of financial conditions and financial risk management.

The knowledge factor is very dynamic. It is subject to changes, as the company gains new practical experience, generating (acquiring) knowledge per se, e.g. as result of education and appropriate knowledge management within the organization. Apart from knowledge, the recognition of export opportunities is another necessary element of successful internationalization. This factor is strictly correlated with available knowledge. Good recognition of expansion opportunities is based on the company's knowledge of its own capabilities as well as on familiarity with foreign markets and their needs. These elements all played a role in the initial internationalization of PWPW.

Moreover, the mode of internationalization applied by PWPW has been largely dependent on very specific customer expectations. A specific form of activity on foreign markets (such as a foreign branch or foreign production) is tied to and results from concrete order specifications. It is a common practice on the market for banknotes and security prints. Therefore, the form of internationalization was not chosen as a result of the producer pushing towards the target solution, which is a popular scenario, but resulted from pulling actions of the ordering party.

In the case of PWPW the experience gained on the domestic market with public administration bodies and adjustment of Polish documents to EU and international standards has also played an important role. Examples include the production of security prints in 2004 ("blank EU visas"), first for Poland and then Austria, Latvia, Switzerland, Greece, Portugal, Slovenia, Netherlands or UK, in the form of ready blank visas or security paper based on EU templates, to be printed-over by local producers.

In the turn of the century, the company was also building its network of international relationships. As previously emphasized, the relationships were formed both with companies of a similar business profile and with suppliers of specialist equipment, technologies and materials, mainly from Western Europe. PWPW's relationships and network position were an important factor enhancing the 
international recognisability of PWPW's brand, enabling the company to learn from other entities in the sector and solve practical technological problems by the processing of specific orders. It also enhanced confidence in PWPW. As a result, the network of mutual relationships based on jointly performed contracts, experience sharing during fairs and international conferences and informal interpersonal meetings, helped the company to acquire new foreign contracts.

The learning process is particularly important in the context of PWPW 's internationalization. On one hand it is based on already possessed knowledge, on the other hand it catalyses new value in the knowledge area. The learning process, not only in the area of internationalization, includes acquiring knowledge through education and raising formal qualifications (specialist training, post-graduate studies etc.) as well as practical experience and experience sharing both within the company, the entire industry and on a cross-industry basis. In the sector of security products and services and in many other sectors there has been some experience-sharing and collaboration with regard to combining IT competencies required for software and IT solutions development (IT companies) with companies experienced in the functionality of national documents and issuance systems as well as physical security features for documents and production security (producers of security prints). Certain investment decisions, such as the purchase of a machine for banknote production with the additional application of state-of-the-art optically variable security features, enabled PWPW to enhance its competencies and expand its offer. Based on its knowledge and position in the network of relationships and assuming the continuous improvement and enhancement of its own, broadly-understood personal and organizational skills, the company has built its image of trust, so important to banknote and document producers. The available technologies, know-how, machine park and high-class specialists are a necessary, but not the only condition of obtaining foreign contracts in PWPW's industry. An additional condition is the customers' trust and - in some cases also on the part of suppliers of raw materials, specialist machines or technologies. Producers of special security inks or optical security features such as holograms, verify not only the buyer but also the end customer and the product type to which the given security feature is applied. Security and observance of high-quality of security products is the primary objective. Another example of a method used to screen trusted partners is the EU list of producers authorized to deliver Schengen visas.

Apart from the above factors, the decision to proceed with a given form of foreign activity was for PWPW of key importance. The decision is connected not only with the assessment of real production capacities, choice of engagement form and financial efficiency analysis, but also - especially at the stage of international position building with the analysis of impact on the company's relationships and network position. The activity on international markets (and not only there) may weaken or strengthen the existing ties with trading partners or create new ones. Caution in this respect is particularly important at the initial state of the internationalization of the firm. An attempt to enter entirely new markets may elicit direct reactions. If there are network relationships between companies and specific companies fulfil dual functions, acting as customers in some contexts and as competitors in others, the decision on engaging in, and on the extent of, internationalization, may and often will affect the relationship between the parties concerned. Examples include sale of security paper (for banknotes 
or passports) to other banknote or security print producers and competition with producers that also supply microchips to some key products of PWPW. At the initial stage of internationalization PWPW's decisions accounted for the competitive forces on the markets and avoided confrontation with PWPW's partners. At the same time, export was chosen as the safest form of internationalization at that stage of development, as it did not require long-term engagement (including financial engagement).

\section{Stage of Broader Foreign Expansion and Long-Term Relationships}

PWPW decided to build its first long-term relationship with a foreign customer in Lithuania. Export exchange with Lithuania was an example of development based on acquired know-how and market knowledge. It was also a form of expanding business relationships enhancing the company's image. PWPW began actual collaboration with Lithuania in 2003, with delivery of security paper for the Lithuanian market, for a local producer of security prints. In the course of further cooperation both with government administration and local partners the company processed small orders for paper and security prints. In 2007 PWPW was awarded a contract (together with its Lithuanian partner) for the delivery of Lithuanian biometric passports, together with associated personalization system. Over the next years, as international regulations and customer requirements were changing, the product was gradually modified - e.g. the second biometric feature (EAC standard) was implemented in passports in 2009. At present, apart from security components to passports, PWPW also delivers its own IT solutions and electronic components for new identification documents in Lithuania. Its success in the 2007 tender for delivery of Lithuanian passports and associated issuance systems was a breakthrough in the company's approach to its own internationalization. The award of the contract was preceded by many months of commercial and marketing efforts, consisting in the analysis of opportunities, creating and maintaining relationships with Lithuanian government authorities, promotion and image creation as well as technical and technological consulting services. Those activities were strongly supported by Polish diplomatic services. There were also various initiatives with potential partners and local producers.

Based on the Lithuanian experience, the company initiated steps to export its products and services on the international market. In order to develop new export operations PWPW had to reorganize its internal structures and previous procedures as well as adopt a new customer and product approach and change the sale process. The most important factors determining further development of PWPW's internationalization were represented by three of the four groups present in the Uppsala model:

1) knowledge and opportunities,

2) learning and trust-building,

3) network position.

The fourth factor of the Uppsala model, relationship commitment decisions, was used with cautions since the company did not want to take risk of large financial consequences of such commitments. The crucial factors of success were knowledge of particular markets and the rules of their functioning as well as promotion and trust- 
building with regard to PWPW's brand. Credible references in international trade were a key to winning public procurement procedures.

After gaining experience and obtaining recommendations, PWPW began its export development activities and new market acquisition with its feature product - security paper. Up until today it has been successfully selling banknotes, passports, visas and high security paper both to end customers and security print producers. Since the beginning of its activity the company has produced security paper with cylinder mould watermarks, security threads, fibres as well as other security features embedded in paper, both cotton and cellulose, through rotary screen printing. Foreign customers' various requirements and standards have led to substantial product development, expanded range of security features, available paper types and improved product parameters. PWPW began producing paper with wider threads and with several security threads embedded within one banknote, paper with window threads, with very small borates (the so-called stardust), with special markers added to the paper pulp, with different parameters of paper surface processing. In the current year alone the company has produced banknote paper for five different global currencies and several passports.

The ability of perfect portrait mapping - facial images, based on drawings, pictures or the existing watermark - became a real challenge in the process of banknote paper manufacturing for other countries. There were certain difficulties with mapping facial features of unknown or exotic persons so that they were recognizable on the watermark by users of the end product. In the case of export paper there was also the element of ethnographic analysis, in particular with regard to characteristic facial features of specific nations, decorative elements or national head coverings unknown in Poland. Source materials provided by customers were supplemented with on-line resources and increased number of trials before the final presentation and acceptance. Issues of correct graphic design mapping have proven to be of key importance in the case of PWPW's banknotes, e.g. the recently printed banknote of 10000 PYG for Paraguay. Perfect mapping of a banknote already in circulation was possible on the basis of the original banknotes, as the customer did not provide any additional materials.

Apart from previous technological documents created for the purposes of internal organization of production, the company developed new standards of technical and delivery documentation on the customer's request. Product quality plans defining the technical parameters, tolerance and methodology of the product as well as control and research measures were particularly important. Apart from the quality plans the company also creates detailed packaging specifications and manufacturing descriptions - the so-called product tracking, or detailed assignment of particular ready reams or sheets to the given production batch. Apart from product manufacturing as such, appropriate organization of transport is also an important issue. The paper produced by PWPW often travels many thousands kilometres to the place of destination by road, sea or air. The product is sensitive to weather conditions and its target parameters, such as humidity, are important for future printing. This should be considered by packaging and transport organization so that each batch is safely received by the end customer. Logistic and formal issues related to contract performance also entail strict requirements concerning shipment and customs documents as well as security, until 
the products are deposited at the customer's (central bank's) treasury. On-going projects allow PWPW not only to improve its production and delivery quality and efficiency, but also to gain better knowledge of specific markets and trading specifics.

The next important category of export products includes identification documents: passports and ID cards as well as other cards with security features - documents for public administration bodies, such as cards for digital tachographs, which are adopted by a growing number of countries. PWPW produces electronic passports and identity documents with biometric data designated for exports. These documents use the widest range of PWPW's competencies. The biometric passport is the best example. The preparation process begins with designing the document, taking into consideration its functions, purpose, conditions of target application and allowing for the customer's requirements as well as international norms and standards. In this way the optimal technical specification of the document and its security features is created. This refers both to the physical and electronic aspects of the document. the physical layer, the design of all foreign documents must include the given nation's symbols, events, traditional art or ornaments, which must be included in the graphic design and the security features of the document. The electronic layer of the document and implementation of the associated issuance system, there is a separate designing process for the entire micro-chip software and system architecture, depending on government requirements, in particular in the case of centralization of the document issuance system. The production of this type of modern solutions requires the company to harness its various capabilities, beginning with the production of security paper and traditional printing with the use of varied printing techniques: offset printing, steel engraving or screen printing. Other required skills include IT development and programming, application of biometry to modern documents, securing electronic data or development of decentralized data capturing systems, personalization system as well as integration of solutions implemented by the customer (e.g. with regard to data base management).

Newly developed solutions must be adjusted to legal as well as statutory regulations on international and local level. Implementation requires close cooperation with customers and local contractors to ensure appropriate logistic management equipment assembly, software implementation, system testing, staff training enabling smooth system operation and maintenance. In this case PWPW, apart from its traditional role of a document manufacturer, also acts as integrator of the entire solution and manager of the entire implementation project. Management of complex, multifaceted projects (involving many internal units of the company, external partners, subcontractors, the customer) is a great challenge and a complicated undertaking. PWPW has a track record of these implementations producing passports for Lithuania, Bangladesh and Armenia.

\section{New Forms of Internationalization}

The international activity of PWPW as described above covers both direct and indirect exports. As the company acquired new competencies and strengthened its position on foreign markets, the scope of various forms of internationalization enlarged by licensing on foreign markets and foreign divisions. 
The Armenian project was one of the most complex ever managed by PWPW. The project covered not only manufacturing biometric passports and electronic identification cards (ID card) but also implementing specific IT functions to the ID cards and passports as well as building and servicing the whole physical and software infrastructure in 60 locations in Armenia. This infrastructure enabled to collect citizens' data (including biometric data), personalize and issue ready documents. Such a project required intensive co-operation with local partners and establishment of own branch in Armenia.

Currently it is impossible to separate documents from their management systems. Modern document systems have a complex electronic layer. A vast scope of knowledge encourages the company to continue its education on different fields. What is important, in the case of PWPW S.A., the producer of public security documents, the role of a public document and its functions both for the citizen and government administration is clear and superior to other aspects of project implementation.

The experience gained by the company by the implementation of new identification documents is commonly used not only by the production of passports and ID cards. PWPW S.A. is successfully combining the sphere of card production with broadly-understood sphere IT in other cards, security IDs and identification cards. Customers are offered individual solutions for card security, such as the PCP technology embedded in the card structure. Examples of completed implementations and currently used products are digital tachograph systems for Armenia and Azerbaijan. Systems issuing digital tachograph cards were implemented in both those countries. PWPW S.A. also produces the tachograph cards and deals with its personalization.

\section{CONCLUSIONS}

The case study of PWPW allows us to conclude that the internationalization process of the company is generally consistent with the revitalized Uppsala model. The process of internationalization is gradual and based on four interrelated aspects, i.e. 1) knowledge and opportunities; 2) network position; 3) relationship commitment decisions; and 4) learning, creating and trust-building. Although certain deviations from the model assumptions are evident. The deviations are connected with the specific nature of the company's business activity concerning banknotes and security prints. It must be emphasized that the choice of the mode of internationalization resulted from pulling actions of the ordering party and not from the producer pushing towards the target solution. It seems that this special form of relationship between the contractor and the ordering party requires further empirical research covering markets other than banknotes and security prints.

The analysis of PWPW's internationalization process shows that it is incremental. Any business relationships with foreign customers (central banks or governments) in the industry of banknotes, IDs and related IT solutions can be only built when the producer ensures that the manufacturing process and distribution will not violate the national security of the client. This condition of trust and reliability requires time. This is one of the reasons for choosing the incremental process of internationalization of PWPW. We can expect that this incremental approach refers to the whole business of 
banknotes, IDs and related IT solutions or even more general, i.e. the all the industries where delivered products or services have a significant influence on the state security.

As it was stated above, PWPW S.A. is currently at a transitional state from "structured export" to "export with strong local engagement" through local representatives, consortia, alliances or its own divisions. The internationalization process, divided into forms and countries of foreign activity is presented in Table 4.

Table 4. The internationalization process of PWPW divided into stages and countries of foreign activity

\begin{tabular}{|c|c|c|}
\hline $\begin{array}{c}\text { Stage I: } \\
\text { ad hoc exports }\end{array}$ & $\begin{array}{c}\text { Stage II: } \\
\text { "structured" exports }\end{array}$ & $\begin{array}{c}\text { Stage III: } \\
\text { exports with local } \\
\text { engagement - } \\
\text { alliances and } \\
\text { divisions }\end{array}$ \\
\hline Ukraine, & USA, Austria, France, the Czech Republic, Germany, Lithuania, & $\begin{array}{c}\text { Bangladesh, } \\
\text { Belarus, }\end{array}$ \\
$\begin{array}{c}\text { Sweden, } \\
\text { Ketherlands, Portugal, Ecuador, Slovenia, Turkey, Bangladesh, } \\
\text { Kirgizstan, Armenia, Azerbaijan, Georgia, Ecuador, Greece, } \\
\text { Czech Republic }\end{array}$ & $\begin{array}{c}\text { Turkey, Belarus } \\
\text { Lithuania, France, Switzerland, Latvia, Germany, Hungary, }\end{array}$ \\
\hline
\end{tabular}

Source: own study

The choice of an appropriate model and business profile is currently determined by two major factors:

1) market knowledge (acquired experience on the given market, knowledge of market structure, distribution channel, competition and created image of PWPW (recognisability and branding)),

2) type of offered and conducted business including end-customer requirements.

In the case of comprehensive contracts, not only for the delivery of security products but also for the implementation of associated, complex and extensive IT systems as well as maintenance and technical support of such systems during contract term, the supplier must be continuously present on the given market. Very often this is directly related to customer requirements, e.g. terms of tender specification, or other conditions, such as technical support response time or good practice in the sector. The above indicators and geographical distance and existing relationships and cooperation determine the ultimate business model for export sales.

Analysis of international activity of specific sectors of companies is not only an interesting object of study, but also a potential contributor of new guidelines for the internationalization process and good practices of firms. PWPW is an example of successful internationalization and thus its experience and chosen patterns can be used by other companies of a similar profile. The position of PWPW on international markets shows that companies from Central and Eastern Europe can effectively compete with Western firms which, are much more experienced in international trade. Moreover, the state nature of ownership, as in case of PWPW, is not necessarily an obstacle in the internationalization process. Moreover, in the business of documents and banknotes production state-owned enterprises such as PWPW have a competitive advantage over private firms. The state as an owner and at the same time the major customer of a domestic banknotes and documents producer provides additional credibility and trust. 
The study reveals critical areas of knowledge and skills possession for banknote and security papers producers in internationalization context. These are important factors of successful attempts of foreign market entry. First, in the market for banknotes and documents, the producer needs to possess knowledge of statutory solutions, in particular those determining the issue of documents and other products as well as organization of public administration, identification of distribution channels for particular products, as well as knowledge of trade and tax law, on local and international level, and customs law. Second, market analysis should also account for the political and economic situation and stability. It is not an easy task, given the current uncertainty. The company must carry out its own, detailed analysis and draft reports from continuous market and customer monitoring. Polish diplomatic services, local partners and sometimes even competitors have supported PWPW's internationalization efforts. The company must also monitor individual countries and their situation in terms of needs, plans and development of specific products and services and current tender procedures. The whole procedure of bid placement in international tender also requires specific knowledge and practical experience. Individual public administration bodies have their own requirements, norms and regulations, and many formal documents, descriptions, presentations, bank guarantees, designs and product templates are required. PWPW must also secure itself local support (business partners, agents, consultants), collaborate with local representatives in opportunity identification and appropriate bid placement. PWPW has been consistently expanding its commercial network for the past few years. Local partners are necessary by contract performance, e.g. in the IT sector, by system implementation and maintenance.

Furthermore, another crucial area of knowledge and skills in the sphere of trade relationships is an appropriate preparation of the export staff due to differences in language, culture and religion. Even casual talks, development of offers and negotiations provide opportunities for improving specific selling skills applicable to the given country and customer, each time adjusted to prevailing standards. For example, English, which seems to be the natural tool of business communication on European markets, is not appropriate for communication in Caucasus, Asia or South America, for instance in Paraguay. In order to serve the entire region of South America, the competencies of PWPW were supplemented with fluency in Spanish. Linguistic alignment is a necessary, but not the only requirement. It is equally important to learn the customs, culture, historical and traditional contexts, geography, politics and international relations of our customers and to understand their mentality and behaviour. While it seems obvious, it is in fact quite difficult to adopt a new perspective and a new perception of the world. Rooted stereotypes rarely prove true. Hence, the specialists employed by export contracts need to have an open mind, knowledge, erudition, long-term experience and should strive towards self-improvement. Errors in business contacts can jeopardize even the best offer. This why the customer or market executives should be specialized in the given market. The company has already organized a separate place of prayer for its Muslim guests or organize warm jackets for Asian customers who came to Warsaw in October in their summer suits. In such situations the company can learn how to arrange all details of trade relationships and to prepare for visits. Anticipation and flexibility is crucial. 
All the presented attempts have resulted in successful internationalization. It could be concluded that after several years of international activity PWPW is sufficiently noticeable both to customers and other companies in the sector (competitors and partners). Not only does PWPW participate in industry exhibitions, seminars, discussion panels, international commissions and decision-making groups, but it also acquires and performs more and more contracts, thus expanding its reference list. Those contracts, orders and references help it to change and strengthen its global image. PWPW is still building its reputation and recognition on the international market. But it is also expanding its range of products and services, technological, commercial competencies and completeness of the offer (integration of traditional manufacturing with IT systems). More and more often, PWPW opts for permanent presence on third markets, both through collaboration with local representatives and through potential local divisions or production facilities. The company is developing proprietary, unique solutions, and export activity motivates it to continuous technological and commercial development. This is beneficial not only for foreign customers, but also for the national public administration, which still is and always will be the key recipient of PWPW's products and services, and may benefit from its achievements, development, experience and capacities.

\section{REFERENCES}

Adamkiewicz-Dwiłło, HG 2008, Współczesna metodologia nauk ekonomicznych, TNOiK, Toruń.

Agarval, S 1994, 'Socio-cultural distance and the choice of joint-ventures: A contingency prospective', Journal of International Marketing, vol. 2, no. 2.

Barkema, HG \& Drogendijk, R 2007,'Internationalising in small, incremental or larger steps?', Journal of International Business Studies, vol. 38, no. 7.

Barney, JB 1991, 'Firm resources and sustained competitive advantage', Journal of Management, vol. 17.

Bonnaccorsi, A 1992, 'On the relationship between firm size and export intensity', Journal of International Business Studies, vol. 23, no. 4.

Capar, N \& Kotabe, M 2003, 'The relationship between international diversification and performance in service firms', Journal of International Business Studies, vol. 34, no. 4.

Daszkiewicz, N \& Wach, K 2012, Internationalization of SMEs. Context, models and implementation, Gdańsk University of Technology Publishers, Gdańsk.

Die Welt, http://www.welt.de/wirtschaft/article1767242/Staat-steigt-wieder-beiBundesdruckerei-ein.html

Domarecki, K 2012, 'Ekspansja zagraniczna polskich firm. Jaki kierunek?', Thinktank, vol. 3, no. 14.

Dunning, JH 1988, Explaining International Production, Unwin, London.

Erramilli, MK 1991, 'The experience factor in foreign market entry behavior of service firms', Journal of International Business Studies, vol. 22, no. 3.

Goerzen, A \& Makino, S 2007, 'Multinational corporation internationalization in the service sector: A study of Japanese trading companies', Journal of International Business Studies, vol. 38, no. 7.

Gorynia, M \& Jankowska, B 2007, 'Teorie internacjonalizacji', Gospodarka Narodowa, vol. 10. 
Hedlund, G \& Kverneland, K 1984, Are establishment and growth patterns for foreign markets changing? The case of Swedish investment in Japan, Institute of International Business, Stockholm School of Economics, Stockholm.

Hirsch, S 1975, 'Product Cycle Model of International Trade', Oxford Bulletin of Economics and Statistics, vol. 4.

Hollensen, S 2001, Global marketing: a market-responsive approach, Prentice Hall, Harlow.

Johanson, J \& Mattson, LG 1988, International relations in industrial systems: A network approach, In Hood, N \& Vahlne, JE (eds.), Strategies in global competition, Croom Helm, London.

Johanson, J \& Vahlne, JE 1977, 'The internationalization process of the firm - a model of knowledge, development and increasing foreign market commitment', Journal of International Business Studies, vol. 8.

Johanson, J \& Vahlne, JE 2009, 'The Uppsala internationalization process model revisited: From liability foreignness to liability of outsidership', Journal of International Business Studies, vol. 40.

Johanson, J \& Wiedersheim-Paul, F 1975, 'The internationalization of the firm - four Swedish cases, Journal of Management Studies, vol. 12.

Juul, M \& Walters, PG 1987, 'The internationalization of Norwegian firms: A study of the UK experience', Journal of International Business Studies, vol. 27, no. 1.

Knight, G \& Cavusgil, ST 1996, 'The born global firm: A challenge to traditional internationalization theory', Advances in International Marketing, vol. 8.

Komor, M 2011, 'Internacjonalizacja handlu w Europie' In Sławińska M (ed.), Handel we współczesnej gospodarce. Źródła i przejawy innowacyjności, Zeszyty Naukowe Uniwersytetu Ekonomicznego w Poznaniu, vol. 175.

Krugman, P 1979, 'A model of innovation, technology transfer, and the world distribution of income', Journal of Political Economy, vol. 87, no. 2.

Lewandowski, R 2014, 'Rola narodowego wytwórcy banknotów, dokumentów i towarzyszących im systemów IT w systemie bezpieczeństwa obrotu gospodarczego i prawnego', In Raczkowski K (ed.), Bezpieczeństwo ekonomiczne obrotu gospodarczego. Ekonomia, Prawo. Zarządzanie, Wolters Kluwer, Warszawa.

Loane, S \& Bell J 2006, 'Rapid internationalisation among entrepreneurial firms in Australia, Canada, Ireland and New Zealand: An extension to the network approach', International Marketing Review, vol. 23, no. 5.

Miesenbock, KJ 1985, 'Small business and exporting: a literature review', International Small Business Journal, vol. 6.

Nakos, G \& Brouthers, K 2002, 'Entry mode choice of SMEs in Central and Eastern Europe', Entrepreneurship Theory and Practice, vol. 27, no. 1.

Nordström, KA 1990, The internationalization process of the firm. Searching for new patterns and explanations, Stockholm School of Economics, Stockholm.

Penrose, E 1959, The Theory of Growth of the Firm, Basil Blackwell, London.

Petersen, B \& Pedersen, T 1997, 'Twenty years after: Support and critique of the Uppsala internationalization model', In Bjorkman, I \& Forsgren, $M$ (eds.), The nature of the international firm, Copenhagen Business School Press, Copenhagen.

Polish Central Statistical Office, http://www.stat.gov.pl/

Posner, M 1961, 'International trade and technical change', Oxford Economic Papers, vol. 13. 
Prahalad, CK \& Hamel, G 1990, 'The core competence and the corporation', Harvard Business Review, May-June.

Przybylska, K 2010, 'Kontrowersje wokół tradycyjnego ujęcia procesu internacjonalizacji przedsiębiorstw', In Dach, Z (ed.), Otoczenie ekonomiczne a zachowania podmiotów rynkowych, PTE, Kraków.

Simon, H 1999, Tajemniczy mistrzowie - studia przypadków, PWN, Warszawa.

Vernon R 1979, 'The product Cycle Hypothesis In a New International Environment', Oxford Bulletin of Economics and Statistics, vol. 2.

Vernon, R 1966, 'International Investment and International Trade In the Product Cycle', The Quarterly Journal of Economics, vol. 2.

Williamson, OE 1975, Markets and Hierarchies: Analysis and Antitrust Implications, The Free Press, New York.

Zahra, S, Ireland R \& Hitt M 2000, 'International expansion by new venture firms: International diversity, mode of market entry, technological learning, and performance', Academy of Management Journal, vol. 43, no. 5.

Zain, M \& Ng SI 2006, 'The impacts of network relationships on firms' internationalization process', Thunderbird International Business Review, vol. 48, no. 2.

\section{Authors}

\section{Remigiusz Lewandowski}

The Strategy \& Marketing Director at PWPW and a guest lecturer at the Faculty of Economic Sciences and Management at Nicolas Copernicus University of Torun where in 2011 he received (with distinction) a PhD degree in economics. His academic interests cover corporate strategy, corporate governance, finance management, economic security and marketing. $\mathrm{Dr}$ Remigiusz Lewandowski Polish Security Printing Works PWPW

\section{Grażyna Rafalska}

The Director of the International Sales Department at Polish Security Printing Works (PWPW S.A.). Mrs. Rafalska has over 15 years of experience in sales of products and services. For the past 10 years has been in charge of export. Since the beginning of her professional career she deals with sales of security products and services. She graduated from Warsaw University of Technology as Master of Science in Printing. In the field of her professional interests are foreign trade, project management, cultural studies, political geography.

\section{Correspondence to:}

Dr Remigiusz Lewandowski PWPW S.A.

ul. Sanguszki 1, 00-222 Warszawa, Poland r.lewandowski@pwpw.pl 
